BMJ Open Ophthalmology

\section{BMJ Open Ophthalmology}

To cite: Kaye SB. BMJ Open Ophthalmology. BMJ Open Ophthalmology 2020;5:e000530. doi:10.1136/ bmjophth-2020-000530
Check for updates

\section{(c) Author(s) (or their} employer(s)) 2020. Re-use permitted under CC BY-NC. No commercial re-use. See rights and permissions. Published by BMJ.

Department of Eye and Vision Science, University of Liverpool, Liverpool, UK

\section{Correspondence to} Professor Stephen B Kaye; sbkaye@bmj.com
BMJ Open Ophthalmology was launched in autumn 2016. Its remit is to provide an openaccess platform for basic, translational and clinical research in ophthalmology and vision Science.

BMJ Open Ophthalmology aims to:

- Publish a broad range of articles of particular clinical, scientific, educational or surgical value on a rapid publication schedule.

- Facilitate a close interaction between basic, translational and clinical sciences through publication and fostering interdisciplinary research.

- Provide an interactive digital platform that is freely available, unrestricted and immediately accessible.

- Provoke scientific debate and clinical commentary in which the readership, authors and public can engage and contribute through both social and multimedia.

Since its launch, the journal has grown significantly, with submitted and accepted papers increasing from 61 and 16 in 2016, to 136 and 59 in 2019 (figure 1), with an overall acceptance rate of $44 \%$. It has also seen a steady increase in the transfer of good quality papers from other BMJ journals.

BMJ Open Ophthalmology has attracted an international authorship with $18 \%$ of papers from Europe, $17 \%$ from the USA and $16 \%$ from Japan, China and India combined.

The mean (median) time to a first decision has reduced from 47 (43) days in 2016 to 40 (20) days in 2019. The mean time from acceptance to online publication is 23 days.

As an open access journal, BMJ Open Ophthalmology has seen a substantial rise in the number of article downloads from around the world. At the time of writing, the top 10 most downloaded papers in 2019 had been accessed a total of 26537 times . The number of citations BMJ Open Ophthalmology articles have received has correspondingly increased from 4 in 2017 to 136 in 2019. BMJ Open Ophthalmology is indexed in the following major databases: Web of Science Core Collection: Emerging Sources Citation Index,
PubMed Central, DOAJ, Google Scholar, and Scopus.

\section{PATIENT AND PUBLIC PARTNERSHIP}

Taking the lead from The BMJ's innovative patient partnership strategy, BMJ Open Ophthalmology encourages authors to partake in similar schemes. As such, authors submitting research papers are required to include a 'Patient and Public Involvement Statement' within the methods section of their paper, describing how they involved patients and the public in their research. BMJ Open Ophthalmology believes that partnering with patients, their carers, support networks and the public is an ethical imperative and essential to improving the quality, safety, value and sustainability of health systems and research.

\section{DATA SHARING}

Sharing the full datasets underlying the results in your article brings many benefits. It enables reuse, reduces research waste and promotes collaboration. Greater transparency increases trust in research results by allowing results to be independently verified. These benefits lead to a more reliable evidence base and a healthier world. In line with The BMJ, BMJ Open Ophthalmology encourages authors to make available as much of the underlying data from their articles as possible (without compromising participant privacy), but the least that is required is the minimum data required to reproduce the results presented in the associated article.

BMJ Open Ophthalmology considers any files generated by authors' research as constituting relevant data. This may be raw or processed data. Examples include (but are not limited to) individual-level de-identified patient data, survey results, interview transcripts, statistical codes, images, videos, spreadsheets, audio files, text files and imaging and scan files.

\section{EDITORIAL BOARD}

The editorial board has grown to include Associate Editors from USA, Japan, the UK and India, with expert representation from 


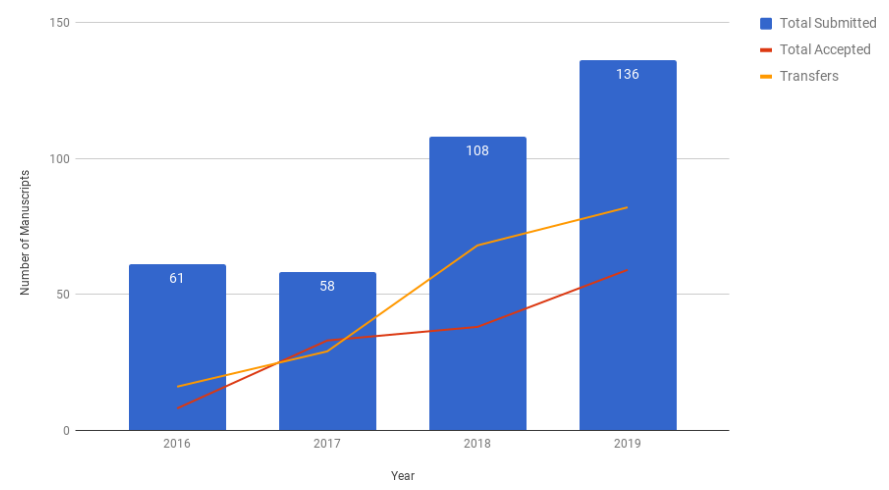

Figure 1 BMJ Open Ophthalmology submissions and acceptances since launch.

all areas of ophthalmology, basic and clinical sciences, and vision science as listed below.

On behalf of the editorial team of BMJ Open Ophthalmology, we wish to thank you for your support of the journal since its launch, and we hope you will join us for the next phase of the journal's development, whether as a reader, author or reviewer.

Editor-in-Chief

Professor Stephen B. Kaye, FRCS, FRCOphth, MD

University of Liverpool

Liverpool, UK

orcid.org/0000-0003-0390-0592

Editorial office: info.bmjophth@bmj.com

Associate Editors

Dr Gabriela Czanner, PhD

University of Liverpool

Liverpool, UK

orcid.org/0000-0002-1157-2093

Area of expertise: Biostatistics

Dr Bernhard Steger, MD

Medical University Innsbruck

Innsbruck, Austria

orcid.org/0000-0002-5316-4661

Area of expertise: Cataract and refractive surgery

Dr Vito Romano, MD

Royal Liverpool University Hospital

Liverpool, UK

orcid.org/0000-0002-5148-7643

Area of expertise: Cataract and refractive surgery

Dr Sajjad Ahmad

PhD, FRCOphth

Moorfields Eye Hospital

London, UK

orcid.org - not available

Area of expertise: Cornea and ocular surface

Professor Stephanie Watson

PhD, FRANZCO

Sydney Eye Hospital

Sydney, Australia

orcid.org/0000-0001-6699-1765

Area of expertise: Cornea and ocular surface

Professor Darlene A. Dartt, PhD

Harvard Medical School
Boston, MA, USA

orcid.org/0000-0002-0576-6932

Area of expertise: Cornea and ocular surface (basic science)

Dr Louise F. Porter, PhD, MSc, MBChB, PhD

University of Liverpool

Liverpool, UK

orcid.org/0000-0002-7406-0319

Area of expertise: Genetics

Dr Ryo Asaoka, MD, PhD

The University of Tokyo

Tokyo, Japan

orcid.org/0000-0001-7182-1912

Area of expertise: Glaucoma

Dr Shunsuke Nakakura, MD, PhD

Saneikai Tsukazaki Hospital

Himeji, Japan

orcid.org/0000-0002-1094-1862

Area of expertise: Glaucoma

Dr Kazunori Hirasawa, MD

Kitasato University

Tokyo, Japan

orcid.org/0000-0001-5100-005X

Area of expertise: Glaucoma

Dr David Yorston, MBChB, FRCOphth, FRCOphth

NHS Greater Glasgow and Clyde

Glasgow, UK

orcid.org/0000-0001-7259-5320

Area of expertise: Global ophthalmology and retina

Ms Savitha Madhusudhan, MBBS, DO, FRCOphth

Royal Liverpool and Broadgreen University Hospital

Liverpool, UK

orcid.org/0000-0002-8203-0929

Area of expertise: Medical retina

Dr Kevin Hamill, PhD

University of Liverpool

Liverpool, UK

orcid.org/0000-0002-7852-1944

Area of expertise: Molecular ophthalmology

Professor Anat Galor, MD, MSPH, MD, MSPH

University of Miami

Miami, FL, USA

orcid.org/0000-0002-3026-6155

Area of expertise: Ocular surface

Dr Saaeha Rauz, PhD, FRCOphth

University of Birmingham

Birmingham, UK

orcid.org/0000-0003-4627-3496

Area of expertise: Ocular surface and translational research

Dr Yalin Zheng, PhD

University of Liverpool

Liverpool, UK

orcid.org/0000-0002-7873-0922

Area of expertise: Ocular imaging

Professor Bhupendra Patel, LRCP, MRCS, MBChB, DORCS, FRCS, FRCOphth

University of Utah 
Salt Lake City, UT, USA

orcid.org/0000-0002-7873-0922

Area of expertise: Oculoplastics and orbit

Dr Ramesh Kekunnaya, MD

L V Prasad Eye Institute

Hyderabad, India

orcid.org/0000-0003-4673-8927

Area of expertise: Paediatric ophthalmology and strabismus

Professor David A. Eichenbaum, MD

Retina Vitreous Associates of Florida

Tampa, FL, USA

orcid.org/0000-0003-0654-0668

Area of expertise: Retina

Dr Michael Williams, MD, MRCOphth, MMedEd

Queens University Belfast

Belfast, UK

orcid.org/0000-0002-5051-5921

Area of expertise: Retina

Dr Sidney Schechet, MD

University of Chicago Medicine

Chicago, US

orcid.org/0000-0001-8996-3855

Area of expertise: Retina

Professor Baljean Dhillon, FRCS, FRCPS, FRCOphth

University of Edinburgh

Edinburgh, UK

orcid.org - not available

Area of expertise: Retina and neurology

Professor Conor Murphy, MBBChBAO, MMedSc, FRCSI, FRCOphth, PhD

Royal College of Surgeons in Ireland
Dublin, Ireland

orcid.org/0000-0003-2171-0418

Area of expertise: Uveitis and ocular inflammatory disease

Professor James Wolffsohn, BSc, PgCertHE, MBA, PhD, PFHEA, FRSB, FCOptom, FAAO

Aston University

Birmingham, UK

orcid.org/0000-0003-4673-8927

Area of expertise: Visual science

Social Media Editor

Dr Mariya Moosajee, MBBS, PhD, FRCOphth

University College London

London, UK

orcid.org/0000-0003-1688-5360

Area of expertise: Genetics

Twitter: @BMJ_Ophth

Contributors Authors own work.

Funding The authors have not declared a specific grant for this research from any funding agency in the public, commercial or not-for-profit sectors.

Competing interests None declared.

Patient consent for publication Not required.

Provenance and peer review Commissioned; internally peer reviewed.

Open access This is an open access article distributed in accordance with the Creative Commons Attribution Non Commercial (CC BY-NC 4.0) license, which permits others to distribute, remix, adapt, build upon this work non-commercially, and license their derivative works on different terms, provided the original work is properly cited, appropriate credit is given, any changes made indicated, and the use is non-commercial. See: http://creativecommons.org/licenses/by-nc/4.0/.

ORCID iD

Stephen B Kaye http://orcid.org/0000-0003-0390-0592 